\title{
Correction to: Dutch Economic Value of Radium-223 in Metastatic Castration-Resistant Prostate Cancer
}

\author{
Michel L. Peters ${ }^{1}$ - Claudine de Meijer ${ }^{2} \cdot$ Dirk Wyndaele $^{3}$ - Walter Noordzij ${ }^{4}$. \\ Annemarie M. Leliveld-Kors ${ }^{5} \cdot J_{0 a n}$ van den Bosch ${ }^{6}$ Pieter H. van den Berg ${ }^{7}$. \\ Agni Baka ${ }^{1} \cdot$ Jennifer G. Gaultney ${ }^{8}$ (i)
}

Published online: 4 January 2018

(C) The Author(s) 2018. This article is an open access publication

\section{Correction to: Appl Health Econ Health Policy https://doi.org/0.1007/s40258-017-0350-x}

The article Dutch Economic Value of Radium-223 in Metastatic Castration-Resistant Prostate Cancer, written by Michel L. Peters, Claudine de Meijer, Dirk Wyndaele, Walter Noordzij, Annemarie M. Leliveld-Kors, Joan van den Bosch, Pieter H. van den Berg, Agni Baka, Jennifer G. Gaultney was originally published electronically on the publisher's internet portal (currently SpringerLink) on 2nd September, 2017 without open access.

The original article can be found online at https://doi.org/10.1007/ s40258-017-0350-x.

Jennifer G. Gaultney

jgaultney@mapigroup.com

1 Real World Strategy and Analytics, Mapi Group, Houten, The Netherlands

2 Bayer B.V., Mijdrecht, The Netherlands

3 Department of Nuclear Medicine, Catharina Ziekenhuis, Eindhoven, The Netherlands

4 Department of Nuclear Medicine and Molecular Imaging, University of Groningen, University Medical Centre Groningen, Groningen, The Netherlands

5 Department of Urology, University of Groningen, University Medical Centre Groningen, Groningen, The Netherlands

6 Department of Internal Medicine, Albert Schweitzer Ziekenhuis, Dordrecht, The Netherlands

7 Department of Internal Medicine, Tergooi Ziekenhuizen, Hilversum, The Netherlands

8 Real World Strategy and Analytics, Mapi Group, The Translation and Innovation Hub Building, 5th Floor, 80 Wood Lane, White City, London W12 OBZ, UK
With the author(s)' decision to opt for Open Choice the copyright of the article changed on 24th November, 2017 to (C) The Author(s) 2017 and the article is forthwith distributed under the terms of the Creative Commons Attribution-NonCommercial 4.0 International License (http:// creativecommons.org/licenses/by-nc/4.0/), which permits any noncommercial use, duplication, adaptation, distribution and reproduction in any medium or format, as long as you give appropriate credit to the original author(s) and the source, a link is provided to the Creative Commons license and any changes made are indicated. The original article was corrected.

\section{Compliance with Ethical Standards}

Funding Open Access was funded by Bayer.

Open Access This article is distributed under the terms of the Creative Commons Attribution-NonCommercial 4.0 International License (http://creativecommons.org/licenses/by-nc/4.0/), which permits any noncommercial use, distribution, and reproduction in any medium, provided you give appropriate credit to the original author(s) and the source, provide a link to the Creative Commons license, and indicate if changes were made. 